\title{
PENGARUH KONTAMINASI INSEKTISIDA PROFENOFOS TERHADAP FISIOLOGIS IKAN NILA MERAH (Oreochromis sp.) (Contamination Effect of Profenofos Insecticide on Physiology of Red Nila (Oreochromis sp.))
}

\author{
Ratih Ida Adharini ${ }^{1 *}$, Suharno² dan Hari Hartiko \\ ${ }^{1}$ Departemen Perikanan, Fakultas Pertanian, Universitas Gadjah Mada, \\ Jl. Flora Gd. A4, Bulaksumur, Yogyakarta, 55281. \\ ${ }^{2}$ Departemen Fisiologi, Fakultas Biologi, Universitas Gadjah Mada, \\ Jl. Teknika Selatan, Sekip Utara, Yogyakarta 55281.
}

*Penulis korespondensi. Tel: 0274-551218. Email: ratih.adharini@ugm.ac.id.

Diterima: 7 Maret 2016
Disetujui: 31 Agustus 2016

\begin{abstract}
Abstrak
Peningkatan jumlah penduduk memicu aktivitas manusia yang cenderung merusak lingkungan. Penggunaan insektisida organofosfat berlebih berdampak pada pencemaran lingkungan perairan dan organisme di dalamnya. Penelitian ini bertujuan untuk mengetahui pengaruh kontaminasi profenofos (insektisida organofosfat) terhadap fisiologis ikan nila merah. $\mathrm{LC}_{50-96}$. Profenofos ditentukan dengan bantuan perangkat lunak Analisis Probit. Aktivitas kolinesterase plasma darah dan jaringan otak diperiksa menggunakan kolinesterase kit (DiaSys) secara spektrofotometri. Laju konsumsi oksigen $\left(\mathrm{LKO}_{2}\right)$ diukur menggunakan respirometer. Kadar hemoglobin diperiksa dengan metode oksihemoglobin, hematokrit diukur dengan metode mikro-hematokrit. Desain penelitian menggunakan rancangan acak lengkap, dianalisis secara statistik dengan Anova. Selanjutnya jika terdapat beda nyata dilanjutkan dengan uji LSD (Least Significant Difference) serta persamaan regresinya. Gejala kematian ikan serta kualitas fisik dan kimia air uji diperiksa setiap hari, kemudian dianalisis secara deskriptif. Toksisitas curacron pada $\mathrm{LC}_{50-96}$ nila merah sebesar 2,105 ppm. Semakin besar dosis menurunkan aktivitas kolinesterase secara nyata $(\mathrm{P}>0,05)$ pada plasma darah dan jaringan otak. $\mathrm{LKO}_{2}$ setelah 1 jam pendedahan mengalami peningkatan, namun setelah 24 jam hingga 96 jam mengalami penurunan $\left(\mathrm{P}>0,01 ; \mathrm{R}^{2}=0,98\right)$. Semakin besar dosis selama 96 jam secara nyata meningkatkan kadar $\mathrm{Hb}(\mathrm{P}>0,05$; $\left.\mathrm{R}^{2}=0,95\right)$ namun tidak beda nyata pada hematokrit $\left(\mathrm{R}^{2}=0,66\right)$. Penggunaan insektisida ramah lingkungan dan monitoring secara terus menerus dapat mengurangi dampak insektisida pada lingkungan perairan dan organisme di dalamnya.
\end{abstract}

Kata kunci: aktivitas kolinesterase, insektisida organofosfat, laju konsumsi oksigen, Oreochromis sp., pencemaran lingkungan.

\begin{abstract}
The increasing of human population triggers on human activities which are tend to impact on environment. Excessive use of organophosphate insecticides impact on pollution of the aquatic environment and also the organisme therein. The objective of this research was to study the effects of profenofos (an organophosphate insecticide) to the physiology of red nila. Preliminary research was conducted to find out the Lethal Concentration (LC $C_{50-96)}$ of profenofos which was determined by software "Probit analysis". Cholinesterase activity of blood plasma and brain tissue was examined spectrofotometically using cholinesterase kit (DiaSys). Rate of oxygen consumption was measured by Johnson's modified respirometer methode. Hemoglobin were measured by oxyhemoglobin and hematocrit by microhematocrit methods, respectively. This research used complete random design. Data were analyzed statistically using analysis of variance (ANOVA), continued with Least Significant Difference (LSD) and regression test. Lethal Concentration $\left(L C_{50-96}\right)$ of profenofos to red nila was $2.10 \mathrm{mg} / \mathrm{L}$. The results indicated that increasing dosage reduced cholinesterase activity $(P<0.05)$ in blood plasma and brain tissue. Oxygen consumption rate increased after 1-hour exposure, but decreased after 24 to 96 hours $\left(P<0.01 ; R^{2}=0.98\right)$. Increasing dosage of profenofos exposure for 96 hours followed with increasing of Hemoglobin level significantly $\left(P<0.05 ; R^{2}=0.95\right)$, but it was not significantly different in hematocrit $\left(P>0.05 ; R^{2}=0.66\right)$. The use of environmentally friendly insecticides and continually monitoring can reduce the impact of insecticides on the environment and organism therein.
\end{abstract}

Keywords: cholinesterase activity, environmental pollution, Oreochromis sp., organophosphate, oxygen consumption rate.

\section{PENDAHULUAN}

Laju pertumbuhan populasi penduduk Indonesia cenderung tinggi, yaitu sebesar $1,40 \%$ pada tahun 2010-2014 (Anonim, 2015 ). Peningkatan populasi penduduk berakibat pada peningkatan kebutuhan pangan. Hal ini terlihat dari hasil produksi padi di Indonesia yang meningkat 
cepat sebanyak 54.088.468 ton pada tahun 2004 menjadi 70.846 .465 ton pada tahun 2014 (Anonim, $2015^{\mathrm{b}}$ ). Usaha pertanian umumnya menggunakan pestisida dalam pengelolaannya. Insektisida merupakan salah satu pestisida mengandung bahan kimia yang digunakan untuk membunuh atau mengendalikan hama (Kadim, 2013). Semakin meningkat produksi pertanian maka penggunaan pestisida juga semakin meningkat. Organofosfat merupakan enzim penghambat asetil kolinesterase yang digunakan untuk berbagai macam pengelolaan untuk menanggulangi hama di seluruh dunia (Jan dkk., 2015) dan merupakan jenis pestisida yang paling banyak digunakan oleh petani (Raini, 2007).

Penggunaan insektisida berlebih pada akhirnya akan menjadi limbah yang mencemari lingkungan. Limbah tersebut akan terbawa aliran air dan terdistribusi meluas ke perairan yang lebih rendah seperti sungai atau kolam budidaya ikan. Penggunaan pestisida berdampak terhadap kelestarian lingkungan hidup, selain itu pembuangan bahan sisa pestisida ke dalam air ataupun pencucian alat-alat aplikasi didalam saluran irigasi atau badan air lainnya merupakan ancaman terhadap biota air (Tarwotjo, 2014). Pestisida tersebut bersifat non selektif, ada pula yang bersifat persisten yang mengakibatkan terjadi bioakumulasi dalam rantai makanan yang akhirnya berdampak pada kehidupan ikan (Singh, 2013). Menurut Rumampuk dkk. (2010), faktor-faktor yang mempengaruhi toksisitas pestisida terhadap ikan dan organisme air adalah suhu, umur dan lama organisme terpapar, serta konsentrasi bahan toksik yang terlarut. Ambang batas pestisida pada air alam di Indonesia ditetapkan sebesar $2 \mathrm{mg} / \mathrm{L}$ (Setiarso dkk., 2011). Menurut Taufik dkk. (2002), penggunaan pestisida dan insektisida tersebut merupakan sumber pencemar potensial bagi budidaya perikanan.

Profenofos merupakan insektisida organofosfat yang memasuki badan air melalui semprotan $84 \%$ dan aliran air 16\% (15\% terlarut dan $1 \%$ teradsorbsi oleh partikel) (Griffin, 1999). Insektisida organofosfat berperan sebagai inhibitor kompetitif yang dapat menghambat aktivitas enzim kolinesterase yang terakumulasi di sistem saraf pusat dan tepi (Srivastava dkk., 2010). Asetilkolin (AchE) peka terhadap pestisida organofosfat atau karbamat, sehingga aktivitas plasma (AchE) dapat digunakan sebagai penanda terhadap paparan pestisida (Bakhshwan dkk., 2009). Brain cholinesterase (ChE) dapat digunakan sebagai biomarker dalam mendiagnosa paparan pestisida organofosfat dan karbamat karena sensitivitasnya terhadap inhibitor (Cong dkk., 2008). Beberapa studi menunjukkan telah terjadi perubahan hematologi saat ikan terdedah oleh suatu zat yang menyebabkan ikan mengalami stress (Mattsson dkk., 2001).

Bahan aktif profenofos merupakan insektisida organofosfat yang paling banyak digunakan oleh para petani karena tidak menyebabkan resistensi pada serangga (Dalimunthe dkk., 2012). Menurut Anonim (2000), profenosos yang mencemari lingkungan perairan dapat mengakibatkan resiko akut dan gangguan fisiologis pada ikan. Penelitian ini bertujuan untuk mengetahui toksisitas insektisida profenofos dan pengaruhnya terhadap laju konsumsi oksigen, aktivitas kolinesterase plasma darah dan jaringan otak, serta pengaruhnya terhadap kadar hemoglobin dan hematokrit ikan nila merah. Penelitian ini diharapkan dapat memberikan informasi tentang toksisitas dan gangguan fisiologis yang diakibatkan oleh profenofos yang mengancam usaha budidaya petani ikan nila merah sehingga upaya pencegahan dan pengelolaan yang tepat dapat diterapkan.

\section{METODE PENELITIAN}

\section{Bahan dan Alat}

Bahan yang digunakan adalah ikan nila merah (Oreochromis sp.) dengan berat masing-masing \pm $30 \mathrm{~g}$ yang diperoleh dari stasiun II unit kolam percobaan Departemen Perikanan UGM, pelet tipe 781-2, EDTA, syringe, kolinesterase kit, sentrifuse, mikrohematokrit, dan spektrofotometer UV-vis.

\section{Prosedur}

\section{Penelitian pendahuluan I \& II}

Penelitian pendahuluan I dilakukan untuk menentukan kisaran kritis konsentrasi ambang bawah dan atas. Dosis yang digunakan adalah kontrol; 0,$01 ; 0,1 ; 1,0 ; 10$ dan $100 \mathrm{mg} / \mathrm{L}$. Berdasarkan hasil penelitian pendahuluan I, maka digunakan ambang bawah $1 \mathrm{mg} / \mathrm{L}$ dan ambang atas $10 \mathrm{mg} / \mathrm{L}$ untuk menentukan dosis yang akan digunakan pada penelitian pendahuluan II. Pada penelitian pendahuluan II, digunakan variasi dosis 1,$35 ; 2,40 ; 4,20$ dan $7,50 \mathrm{mg} / \mathrm{L}$. Hasil pengujian dianalisis probit untuk menentukan $\mathrm{LC}_{50-96}$ sebagai dasar penentuan dosis pada penelitian utama.

\section{Penelitian Utama}

Dosis penelitian utama yang digunakan untuk mengukur aktivitas kolinesterase, laju konsumsi oksigen, kadar hemoglobin dan hematokrit selama 1 jam adalah dua dosis di atas dan di bawah $\mathrm{LC}_{50-96}$, yaitu kontrol; 0,$75 ; 1,50 ; 2,25$ dan $3,00 \mathrm{mg} / \mathrm{L}$. Sedangkan penelitian utama selama 96 jam menggunakan dosis di bawah $\mathrm{LC}_{50-96}$ yaitu kontrol; 0,75 dan $1,50 \mathrm{mg} / \mathrm{L}$ dengan asumsi ikan masih bertahan hidup sehingga semua parameter dapat diamati. 


\section{Penyiapan plasma darah dan jaringan otak}

Darah diambil dari vena caudalis menggunakan jarum suntik $(1 \mathrm{~mL})$ yang dibasahi EDTA, kemudian ditampung dalam ependorf. Darah disentrifus (Eppendorf, Jerman) $3500 \mathrm{rpm}$ selama 15 menit, kemudian supernatannya diambil sebagai plasma darah. Jaringan otak diperoleh dengan cara membedah kepala dari cavum oris ke arah posterior, kemudian jaringan otak diambil, ditampung dalam ependorf dan dihomogenasi dengan larutan sukrosa 0,25 M. Setelah homogen, sampel disetrifus dengan kecepatan $3500 \mathrm{rpm}$ selama 25 menit, kemudian supernatan diambil.

\section{Pengukuran aktivitas kolinesterase plasma darah dan jaringan otak}

Aktivitas kolinesterase plasma darah dan jaringan otak diperiksa menggunakan kolinesterase kit (DiaSys GmbH, Jerman). Selanjutnya supernatan diukur dan dianalisis menggunakan spektrofotometer (Thermospectronic Genesys 20, Jerman).

\section{Pengukuran laju konsumsi oksigen}

Laju konsumsi oksigen diukur dengan metode respirometer sistem air mengalir. Ikan setelah perlakuan dimasukkan kedalam respirometer berisi air perlakuan. Aliran air masuk dan keluar diatur hingga stabil, dipastikan tidak ada gelembung udara dalam respirometer. Setelah stabil, oksigen terlarut awal (OT 1) dan debit air diukur untuk menentukan waktu retensi (volume respirometer:debit), yang berguna untuk menentukan waktu pengambilan oksigen akhir (OT 2). Pengukuran oksigen terlarut menggunakan Water Quality Checker (DKK-TOA, Jepang). Konsumsi oksigen diukur sebagai laju konsumsi oksigen $\left(\mathrm{mg} \mathrm{O}_{2} / \mathrm{kg} / \mathrm{jam}\right)$ dengan rumus :

Laju Konsumsi Oksigen $=\frac{\text { Oksigen terlburut awal }- \text { Oksigen terlarut akhdr }}{\text { Berat than }} \mathrm{debit}$

Pengukuran hematokrit dan kadar hemoglobin

Hematokrit diukur dengan metode mikrohematokrit. Kadar hemoglobin diukur dengan metode oksihemoglobin menggunakan Linear
Absorbance Spektrofotometer (LAS) (Coleman 44; Perkin Elmer, USA).

\section{Pengukuran kualitas air uji}

Oksigen terlarut (DO), $\mathrm{pH}$, suhu, konduktivitas dan salinitas diukur dengan Water Quality Checker (DKK TOA, Jepang). Kandungan karbondioksida dan alkalinitas diukur dengan metode titrasi.

\section{Analisis data}

Hasil pengamatan aktivitas kolinesterase plasma darah dan jaringan otak, laju konsumsi oksigen, hemoglobin dan hematokrit dianalisis menggunakan Anova. Jika terjadi beda nyata akan dilanjutkan dengan uji LSD (Least Significant Difference) dan regresi. Gejala kematian ikan dan kualitas fisik dan kimia air uji diamati setiap hari dan dianalisa secara deskriptif.

\section{HASIL DAN PEMBAHASAN}

Kontaminasi insektisida profenofos telah mengakibatkan berbagai gangguan metabolisme dan fisiologis pada ikan nila merah (Oreochromis sp.). Gangguan tersebut di antaranya adalah gangguan enzim kholinesterase pada plasma darah dan otak, laju konsumsi oksigen, dan hematologi ikan.

\section{Toksisitas Profenofos}

Semakin besar dosis dan lama pendedahan maka mortalitas ikan nila semakin meningkat (Tabel 1). Toksisitas profenofos terhadap ikan nila merah pada $\mathrm{LC}_{50-96}$ sebesar $2,105 \mathrm{mg} / \mathrm{L}$. Kematian ini disebabkan oleh penghambatan aktivitas kolinesterase sehingga terjadi akumulasi asetilkolin yang mengakibatkan perangsangan syaraf terganggu. Penghambatan kolinesterase dapat terjadi di otak maupun neuromusculare junction pada otot-otot pernafasan yang menggerakkan operkulum maupun tapis insang (gill rackers). Jika penghambatan kolinesterase berlangsung dalam waktu tertentu akan mengakibatkan paralisis otototot pernafasan sehingga proses respirasi dan osmoregulasi terganggu. Lendir yang berlebih di permukaan insang dan kulit menghalangi masuknya oksigen terlarut ke dalam tubuh serta penurunan

Tabel 1. Mortalitas ikan nila merah (Oreochromis sp.) yang terdedah profenofos pada penelitian pendahuluan II.

\begin{tabular}{ccccc}
\hline Perlakuan & \multicolumn{4}{c}{ Mortalitas $(\%)$} \\
Dosis $(=\mathrm{mg} / \mathrm{L})$ & 24 jam & 48 jam & 72 jam & 96 jam \\
\hline 0,00 & $0 \pm 0,00$ & $0 \pm 0,00$ & $0 \pm 0,00$ & $0 \pm 0,00$ \\
1,35 & $0 \pm 0,00$ & $16,7 \pm 5,77$ & $26,7 \pm 15,27$ & $30,0 \pm 10,00$ \\
2,40 & $0 \pm 0,00$ & $26,7 \pm 5,77$ & $36,7 \pm 5,77$ & $50,0 \pm 10,00$ \\
4,20 & $0 \pm 0,00$ & $40,0 \pm 10,00$ & $63,3 \pm 11,55$ & $86,7 \pm 5,77$ \\
7,50 & $0 \pm 0,00$ & $63,3 \pm 11,55$ & $80,0 \pm 10,00$ & $96,7 \pm 5,77$ \\
\hline
\end{tabular}

Sumber : Hasil analisis. 
Tabel 2. Hasil pengamatan kualitas air selama penelitian.

\begin{tabular}{|c|c|c|c|c|c|c|c|c|c|}
\hline Waktu & Perlakuan & $\begin{array}{c}\mathrm{DO} \\
(\mathrm{mg} / \mathrm{L})\end{array}$ & $\begin{array}{c}\mathrm{CO}_{2} \\
(\mathrm{mg} / \mathrm{L})\end{array}$ & $\mathrm{pH}$ & $\begin{array}{c}\text { Suhu } \\
\text { air }\left({ }^{\circ} \mathrm{C}\right)\end{array}$ & $\begin{array}{c}\text { Turbiditas } \\
\text { (NTU) }\end{array}$ & 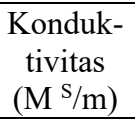 & $\begin{array}{c}\text { Alkalinitas } \\
(\mathrm{mg} / \mathrm{L})\end{array}$ & $\begin{array}{c}\text { Salinitas } \\
(0 / 00)\end{array}$ \\
\hline \multirow{5}{*}{1} & $\mathrm{P} 0$ & 3,94 & 14,0 & 8,2 & 25,8 & 3 & 43,4 & 7,45 & 0.017 \\
\hline & P1 & 2,78 & 14,4 & 7,3 & 26,5 & 3 & 34,4 & 5,5 & 0,016 \\
\hline & $\mathrm{P} 2$ & 2,43 & 15,0 & 7,1 & 26,5 & 3 & 35,1 & 5,6 & 0,018 \\
\hline & P3 & 2,12 & 15,6 & 7,2 & 26,2 & 4 & 37,7 & 5,7 & 0,019 \\
\hline & P4 & 1,70 & 34,0 & 6,9 & 26,2 & 4 & 35,0 & 6,0 & 0,018 \\
\hline \multirow{5}{*}{24} & P0 & 3,14 & 12,0 & 8,0 & 25,5 & 4 & 42,4 & 6,5 & 0,016 \\
\hline & P1 & 2,05 & 14,2 & 7,3 & 26,8 & 3 & 35,0 & 6,15 & 0,018 \\
\hline & $\mathrm{P} 2$ & 1,95 & 14,0 & 7,3 & 26,5 & 3 & 34,2 & 6,2 & 0,017 \\
\hline & P3 & 1,52 & 12,2 & 7,5 & 26,2 & 3 & 37,7 & 6,14 & 0,019 \\
\hline & P4 & 1,24 & 10,4 & 7,0 & 26,3 & 3 & 34,9 & 6,5 & 0,017 \\
\hline \multirow{5}{*}{48} & P0 & 2,66 & 12,2 & 7,8 & 25,3 & 4 & 40,4 & 6,5 & 0,016 \\
\hline & P1 & 1,64 & 15,0 & 7,4 & 25,8 & 3 & 35,2 & 6,2 & 0,018 \\
\hline & $\mathrm{P} 2$ & 1,18 & 13,0 & 7,4 & 25,6 & 2 & 35,5 & 6,1 & 0,018 \\
\hline & P3 & 0,71 & 14,8 & 7,4 & 25,5 & 3 & 38,3 & 6,4 & 0,019 \\
\hline & P4 & 0,52 & 16,8 & 7,2 & 25,4 & 3 & 35,3 & 6,5 & 0,018 \\
\hline \multirow{5}{*}{72} & P0 & 2,40 & 14,0 & 7,8 & 25,6 & 4 & 40,8 & 7,4 & 0,017 \\
\hline & P1 & 2,08 & 17,8 & 7,4 & 26,5 & 3 & 34,4 & 7,5 & 0,018 \\
\hline & $\mathrm{P} 2$ & 1,90 & 17,4 & 7,5 & 26,3 & 4 & 35,7 & 7,5 & 0,018 \\
\hline & P3 & 1,43 & 16,8 & 7,5 & 26,0 & 3 & 35,9 & 7,5 & 0,019 \\
\hline & $\mathrm{P} 4$ & 0,87 & 17,0 & 7,5 & 25,8 & 4 & 38,9 & 7,5 & 0,018 \\
\hline \multirow{5}{*}{96} & P0 & 2,13 & 12,2 & 7,8 & 26,0 & 3 & 43,7 & 6,75 & 0,016 \\
\hline & $\mathrm{P} 1$ & 1,99 & 10,2 & 7,6 & 26,1 & 3 & 35,7 & 6,25 & 0,018 \\
\hline & $\mathrm{P} 2$ & 1,74 & 12,8 & 7,5 & 25,8 & 2 & 36,0 & 6,40 & 0,018 \\
\hline & P3 & 0,87 & 13,8 & 7,4 & 25,6 & 2 & 38,9 & 6,45 & 0,020 \\
\hline & $\mathrm{P} 4$ & 0,55 & 15,2 & 7,3 & 25,4 & 2 & 36,0 & 6,40 & 0,018 \\
\hline
\end{tabular}

Sumber : Hasil analisis.

oksigen terlarut dalam air selama penelitian (Tabel 2) mendukung terjadinya hipoksia jaringan sehingga ikan mengalami stres dan kematian.

Kualitas air selama penelitian cenderung normal, namun semakin besar dosis dan lama pendedahan terjadi penurunan oksigen terlarut (Tabel 2). Hal ini diduga disebabkan oleh banyaknya ekskresi lendir ikan yang terlarut dalam air uji sehingga dapat menurunkan kandungan oksigen terlarut.

Aktivitas kolinesterase plasma darah pada profenofos cenderung lebih rendah dibanding jaringan otak tetapi keduanya mempunyai peran penghambatan yang sama. Namun peneliti mengamati bahwa ternyata ikan yang terdedah pada dosis rendah $(0,75 \mathrm{mg} / \mathrm{L})$ setelah 72 jam pendedahan mengalami pemulihan kondisi ditunjukkan dengan aktivitas kolinesterase dan laju konsumsi oksigen menuju normal.

Ikan yang keracunan profenofos secara umum mempunyai ciri-ciri warna tubuh pucat, banyak lapisan lendir di permukaan tubuh dan insang, dan insang bewarna coklat tua, operkulum membuka dan menutup secara cepat. Menurut Singh (2013), hal ini terjadi untuk melindungi insang agar intensitas terpapar zat racun menurun. Nafas ikan terengah-engah, terjadi ram jet ventilation yaitu gerak cepat dan tidak beraturan. Ikan yang mati dalam kondisi mulut dan operkulum terbuka, sirip dada dan sirip perut kaku melengkung kearah anterior, sirip punggung kaku mengembang, warna tubuh pucat dan berlendir (Tabel 3). Menurut Wang dkk. (2015), insektisida organofosfat bekerja menghambat aktivitas enzim kolinesterase (AChE) dan berpotensi menggangu tingkah laku spesies yang kemungkinan merupakan sebagai upaya untuk bertahan hidup. Gejala keracunan insektisida organofosfat akut berkembang selama atau setelah pemaparan yang berlangsung dalam hitungan menit ke jam tergantung pada metode penerapannya (Kazemi dkk., 2012).

Rerata laju konsumsi oksigen, hematokrit dan kadar hemoglobin pada pendedahan dosis 0,75 $\mathrm{mg} / \mathrm{L}$ dan kontrol menunjukkan tidak berbeda nyata $(\mathrm{P}>0,05)$, namun berbeda nyata pada dosis 1,50 ; 2,25 dan 3,00 mg/L $(\mathrm{P}<0,05)$ (Tabel 4). Rerata aktivitas kolinesterase plasma darah dan otak pada dosis 1,$50 ; 2,25$ dan $3,00 \mathrm{mg} / \mathrm{L}$ berbeda nyata terhadap kontrol $(\mathrm{P}<0,05)$. Semakin besar dosis pendedahan akan terjadi penurunan aktivitas dosis. Hal ini membuktikan bahwa telah terjadi gangguan berupa penghambatan kerja pada enzim kolinesterase. 
Tabel 3. Gejala umum kematian ikan nila merah (Oreochromis sp.) selama penelitian.

\begin{tabular}{cl}
\hline Waktu & \multicolumn{1}{c}{ Gejala pada Ikan } \\
\hline 24 & $\begin{array}{l}\text { P0: bergerombol di dasar sangat responsif, insang merah cerah } \\
\text { P1: bergerombol di dasar, responsif, berenang mengelilingi bak } \\
\text { P2: berenang menyebar, respon agak lambat, operkulum cepat, nafas terengah-engah, } \\
\text { gerak tidak beraturan }\end{array}$ \\
& $\begin{array}{l}\text { P0: berenang bergerombol, gerakan normal, responsif, warna cerah } \\
\text { P1: berenang menyebar, kurang responsif, operkulum cepat, berlendir } \\
\text { P2: berenang menyebar, menabrakkan diri pada dinding bak, operculum cepat, warna } \\
\text { agak pucat dan berlendir }\end{array}$ \\
& $\begin{array}{l}\text { P0: berenang bergerombol, gerakan normal, responsif, warna cerah } \\
\text { P1: kurang responsif, berenang di permukaan, gerakan lemah } \\
\text { P2: ada kematian ikan, gerakan lemah, operkulum terbuka, warna pucat dan berlendir, } \\
\text { berenang di permukaan }\end{array}$ \\
& $\begin{array}{l}\text { P0: semua ikan masih tampak normal dan responsif } \\
\text { P1: gerakan ikan kembali normal, responsif } \\
\text { P2: ada kematian ikan, gerakan sangat lemah, operkulum terbuka, warna pucat dan } \\
\text { berlendir, berenang di permukaan, nafas terengah-engah }\end{array}$ \\
\hline
\end{tabular}

Tabel 4. Rerata laju konsumsi oksigen $\left(\mathrm{LKO}_{2}\right)$, hematokrit, kadar $\mathrm{Hb}$, aktivitas kolinesterase plasma darah dan otak ikan nila merah yang terdedah Profenofos pada berbagai konsentrasi selama 1 jam.

\begin{tabular}{cccccc}
\hline $\begin{array}{c}\text { Dosis } \\
(\mathrm{mg} / \mathrm{L})\end{array}$ & $\begin{array}{c}\text { Rerata } \\
\mathrm{LKO}_{2} \\
(\mathrm{mg} \mathrm{O} / \mathrm{kg} / \mathrm{jam})\end{array}$ & $\begin{array}{c}\text { Rerata } \\
\text { hematokrit }(\%)\end{array}$ & $\begin{array}{c}\text { Rerata kadar } \\
\mathrm{Hb}(\mu / \mathrm{L})\end{array}$ & $\begin{array}{c}\text { Rerata aktivitas } \\
\text { ChE plasma } \\
\text { darah }(\mu / \mathrm{L})\end{array}$ & $\begin{array}{c}\text { Rerata aktivitas } \\
\text { ChE otak }(\mu / \mathrm{L})\end{array}$ \\
\hline 0 & $399,20^{\mathrm{a}}$ & $18,20^{\mathrm{a}}$ & $3,63^{\mathrm{a}}$ & $479,50^{\mathrm{a}}$ & $502,33^{\mathrm{a}}$ \\
0,75 & $494,37^{\mathrm{a}}$ & $18,35^{\mathrm{a}}$ & $4,06^{\mathrm{a}}$ & $205,50^{\mathrm{b}}$ & $251,17^{\mathrm{b}}$ \\
1,50 & $577,50^{\mathrm{b}}$ & $22,02^{\mathrm{b}}$ & $5,26^{\mathrm{b}}$ & $159,83^{\mathrm{b}}$ & $182,67^{\mathrm{b}}$ \\
2,25 & $611,80^{\mathrm{b}}$ & $22,98^{\mathrm{b}}$ & $5,30^{\mathrm{b}}$ & $137,00^{\mathrm{b}}$ & $137,00^{\mathrm{b}}$ \\
3,00 & $691,80^{\mathrm{b}}$ & $23,77^{\mathrm{b}}$ & $5,40^{\mathrm{b}}$ & $45,67^{\mathrm{c}}$ & $68,50^{\mathrm{c}}$ \\
\hline
\end{tabular}

Keterangan: Rerata dalam satu kolom yang diikuti huruf superscript yang sama tidak berbeda nyata (P $>0,05)$.

\section{Aktivitas Kolinesterase Plasma Darah}

Pendedahan selama 1 jam berpengaruh sangat nyata menurunkan aktivitas kolinesterase plasma darah $(\mathrm{P}<0,01)$ dengan persamaan:

$\mathrm{Y}=49,30 \mathrm{x}^{2}-272,74 \mathrm{x}+448,19 ; \mathrm{R}^{2}=0,92$

Pendedahan tiap 24 hingga 96 jam berpengaruh menurunkan aktivitas kolinesterase plasma darah $\left(\mathrm{P}<0,05 ; \mathrm{R}^{2}=0,96\right)$ (Gambar 1).

Perlakuan dosis 0,75 dan $1,50 \mathrm{mg} / \mathrm{L}$ setelah 1 jam menunjukkan aktivitas kolinesterase yang rendah dibanding kontrol. Hal ini akibat tingkat keracunan profenofos di plasma darah sudah semakin tinggi menyebabkan sistem metabolisme, pernafasan dan persyarafan telah rusak dan sudah tidak dapat diperbaiki sehingga mengakibatkan kematian. Namun P1 (dosis $0,75 \mathrm{mg} / \mathrm{L}$ ) pada jam ke-72 mulai mengalami peningkatan aktivitas kolinesterase. Hal ini diduga karena tingkat racun profenofos mulai berkurang dan tubuh sudah dapat mensintesis kembali enzim kolinesterase meskipun masih dibawah normal. Hal ini juga terjadi pada juvenile Stizosterodion vitreum vitreum yang terpapar Malathion. Aktivitas kolinesterase otak turun hingga nilai yang minimum setelah 12 jam, kemudian secara bertahap mengalami pemulihan hingga 80\% setelah 21 hari (Cong dkk., 2008).

\section{Aktivitas Kolinesterase Jaringan Otak}

Semakin tinggi dosis yang didedahkan selama 1 jam berpengaruh sangat nyata menurunkan aktivitas kolinesterase jaringan otak $(\mathrm{P}<0,0$ dengan persamaan:

$$
\mathrm{y}=55,08 \mathrm{x}^{2}-290,09 \mathrm{x}+468,41 ; \mathrm{R}^{2}=0,98
$$

Pendedahan tiap 24 hingga 96 jam berpengaruh nyata menurunkan aktivitas kolinesterase jaringan otak $\left(\mathrm{P}<0,05 ; \mathrm{R}^{2}=0,95\right)$ (Gambar 2).

Profenofos diduga menembus blood brain barrier sehingga mampu melakukan penghambatan enzim kolinesterase di otak dan sistem persyarafan lainnya. Penghambatan ini terjadi karena insektisida organofosfat berikatan dengan asetil kolinesterase molekul dan berbagi struktur kimia yang sama (Paudyal, 2008). Asetilkolin berfungsi sebagai neurotransmiter universal pada sistem syaraf pusat dan ganglia autonomik, sehingga jika terjadi akumulasi asetilkolin akan terjadi peningkatan perangsangan syaraf yang mengakibatkan hiperaktivitas. Tarwotjo dkk. (2014) yang menyatakan bahwa penghambatan asetilkolinesterase mengakibatkan persimpangan saraf tidak mampu menghentikan rangsangan saraf. Penghambatan kolinesterase jaringan otak oleh profenofos diduga menyebabkan terganggunya 
sistem pusat pernafasan di otak dengan mempengaruhi efek muskarinik dan nikotinik. Efek muskarinik asetilkolin meningkatkan sekresi bronkhial dan konstriksi otot-otot sistem pernafasan, terbukti dengan adanya sekresi lendir berlebihan pada insang dan kulit ikan yang terdedah profenofos dibanding kontrol. Efek nikotinik menyebabkan asetilkolin diseluruh ganglia dan otot skelet melakukan peningkatan kontraksi berlebihan sehingga terjadi hiperaktivitas dan paralisis otot. Paralisis otot-otot pernafasan merupakan faktor penyebab utama terjadinya kematian ikan akibat kegagalan pernafasan. Hal ini ditunjukkan dengan penurunan laju konsumsi oksigen, nafas yang terengah-engah dan gerak buka tutup operkulum yang melemah pada pendedahan dosis $1,50 \mathrm{mg} / \mathrm{L}$ setelah 96 jam pendedahan. Namun jika suplai energi yang dibutuhkan semakin terbatas karena hipoksia dan kondisi tubuh semakin menurun akibat kegagalan pernafasan maka akan semakin mempercepat kematian. Hasil yang sama juga diamati oleh Bakhshwan dkk. (2009), bahwa diazinon (pestisida organofosfat) mempengaruhi terjadinya kelainan klinis pada gangguan saraf dan pernafasan pada lele (Clarias gariepinus).

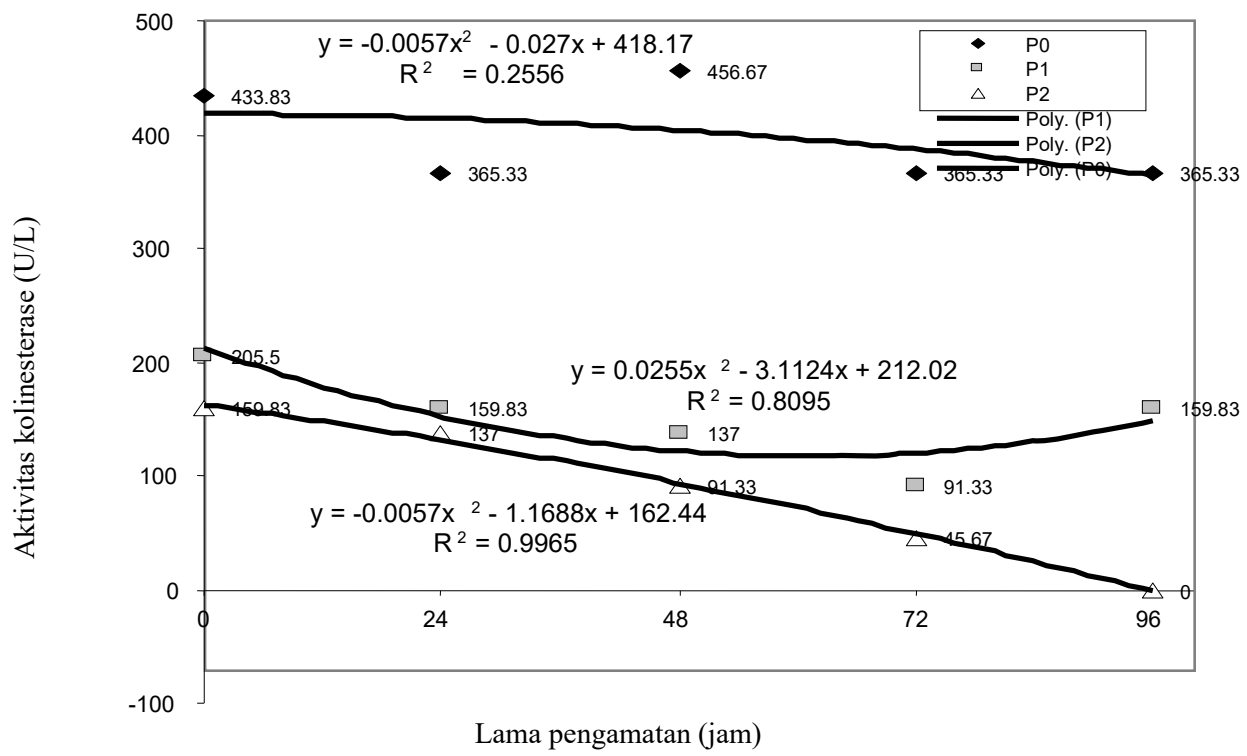

Gambar 1. Hubungan antara dosis profenofos dan aktivitas kolinesterase plasma darah hingga 96 jam. Keterangan: $\mathrm{P} 0=$ kontrol; $\mathrm{P} 1=$ dosis $0,75 \mathrm{mg} / \mathrm{L}$; P2=dosis $1,50 \mathrm{mg} / \mathrm{L}$.

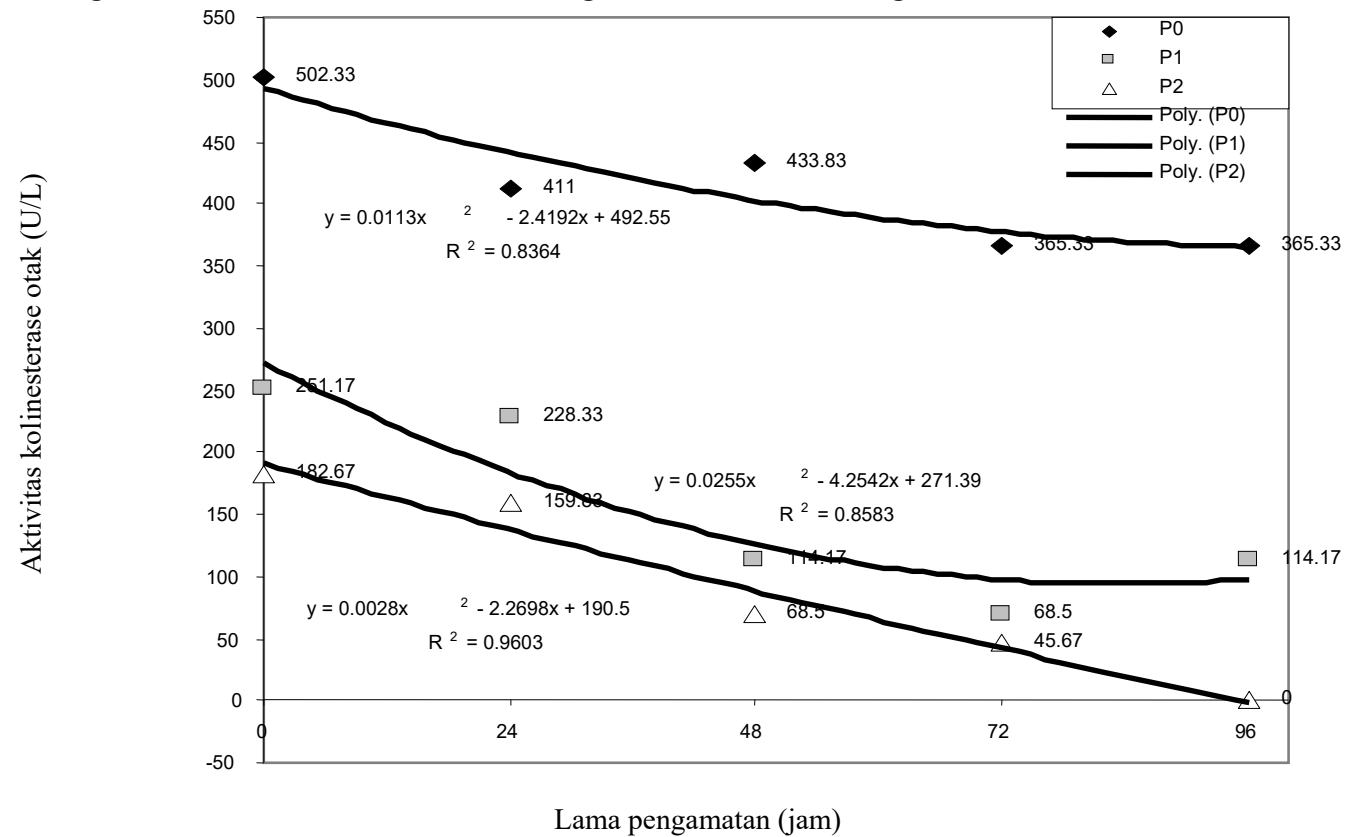

Gambar 2. Hubungan antara dosis organofosfat profenofosdan aktivitas kolinesterase jaringan otak hingga 96 jam. Keterangan: $\mathrm{P} 0=$ kontrol; $\mathrm{P} 1=$ dosis $0,75 \mathrm{mg} / \mathrm{L} ; \mathrm{P} 2=\mathrm{dosis} 1,50 \mathrm{mg} / \mathrm{L}$. 


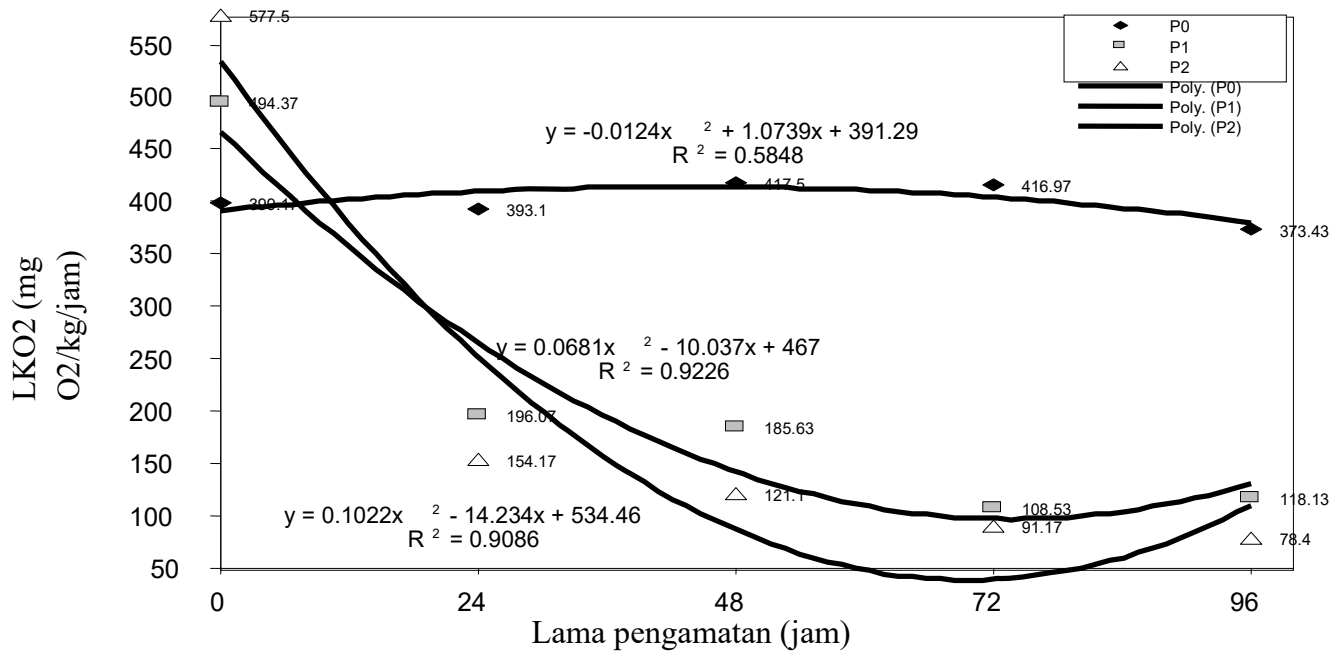

Gambar 3. Hubungan antara dosis profenofos dan $\mathrm{LKO}_{2}$ hingga 96 jam. Keterangan: $\mathrm{P} 0=$ kontrol; $\mathrm{P} 1=$ dosis $0,75 \mathrm{mg} / \mathrm{L} ; \mathrm{P} 2=$ dosis $1,50 \mathrm{mg} / \mathrm{L}$.

\section{Laju Konsumsi Oksigen $\left(\mathrm{LKO}_{2}\right)$}

Semakin tinggi dosis profenofos maka $\mathrm{LKO}_{2}$ selama 1 jam meningkat $(\mathrm{P}<0,01)$ dengan persamaan:

$\mathrm{y}=-54,97 \mathrm{x}^{2}+232,77 \mathrm{x}+379,94 ; \mathrm{R}^{2}=0,85$

Peningkatan $\mathrm{LKO}_{2}$ terjadi karena ikan dalam keadaan stress akibat penghambatan aktivitas kolinesterase. Keadaan ini juga diperparah dengan semakin menurunnya kandungan oksigen terlarut dalam air. Lapisan lendir yang berlebih dan perubahan warna insang menjadi kecoklatan menandakan telah terjadi kerusakan histologis insang yang memicu terjadinya hipoksia. Menurut Srivastava (2010), akumulasi lendir dan perubahan warna pada insang tersebut merupakan gejala reaksi inflamatori insang terhadap polutan. Namun pada akhirnya laju konsumsi oksigen semakin menurun hingga 96 jam jika dibandingkan dengan kontrol $\left(\mathrm{P}<0,01 ; \mathrm{R}^{2}=0,98\right)($ Gambar 3$)$.

Hal ini diduga karena pada jam ke-72 dan -96 otot-otot pernafasan telah mengalami kerusakan sehingga tidak berfungsi normal. Selain itu, penghambatan aktivitas enzim kolinesterase semakin kuat sehingga mengakibatkan kegagalan pernafasan yang ditunjukkan dengan semakin menurunnya $\mathrm{LKO}_{2}$ bahkan dapat berakibat pada kematian ikan.

\section{Kadar Hemoglobin}

Pendedahan selama 1 jam meningkatkan kadar hemoglobin $(\mathrm{P}<0,01)$ dengan persamaan:

$y=-0,23 x^{2}+1,33 x+3,51 ; R^{2}=0,93$

Peningkatan ini dipicu oleh kondisi hipoksia jaringan sehingga hati menghasilkan globulin dan plasma (eritropoetinogen) untuk melakukan proses eritropoietin. Eritropoietin menyebabkan produksi enzim ALS (Amino Levulinic Sintetase) meningkat sehingga sintesis hemoglobin juga meningkat (Banks, 1981). Pendedahan dosis 0; 0,75 dan 1,50 $\mathrm{mg} / \mathrm{L}$ tiap 24 hingga 96 jam berpengaruh nyata meningkatkan kadar hemoglobin $\left(\mathrm{P}<0,05 ; \quad \mathrm{R}^{2}=\right.$ 0,95) (Gambar 4).

Pada dosis $0,75 \mathrm{mg} / \mathrm{L}$ (P1), jam ke-96 terjadi penurunan kadar hemoglobin, diduga daya racun profenofos mulai menurun dan metabolisme tubuh kembali normal sehingga produksi hemoglobin mulai stabil. Hal yang sama juga dilaporkan oleh Supriyono dkk. (2005), dimana setelah pendedahan 48 ke 72 dan 96 jam ikan nila berhasil beradaptasi dan mentoleransi penyerapan triklorfon untuk semakin bertahan dan mengurngi mortalitas. Sebaliknya, P2 (1,50 mg/L) pada jam ke-72 terus mengalami peningkatan hingga jam ke-96. Namun diduga pada waktu tertentu akan terjadi gangguan proses pembentukan hemoglobin sehingga ikan tidak mampu lagi memproduksi hemoglobin yang berakibat pada kematian ikan.

\section{Hematokrit}

Pendedahan selama 1 jam meningkatkan hematokrit $(\mathrm{P}<0,05)$ dengan persamaan:

$\mathrm{Y}=-0,18 \mathrm{x}^{2}+2,65+17,71 ; \mathrm{R}^{2}=0,91$

Pendedahan tiap 24 hingga 96 jam berpengaruh sangat nyata meningkatkan hematokrit $(\mathrm{P}<0,01$; $\left.\mathrm{R}^{2}=0,66\right)($ Gambar 5). Hal ini juga selaras dengan penelitian Carvalho dan Fernandes (2006), di mana juga terjadi perubahan hematologi Prochilodus scrofa dalam merespon pendedahan tembaga pada $\mathrm{pH}$ dan temperatur berbeda yang mengakibatkan goncangan pertukaran ion dan sistem pernafasan yang diindikasikan dengan terjadinya peningkatan konsumsi energi untuk memperbaiki homeostasis dan fungsi fisiologi lainnya. 


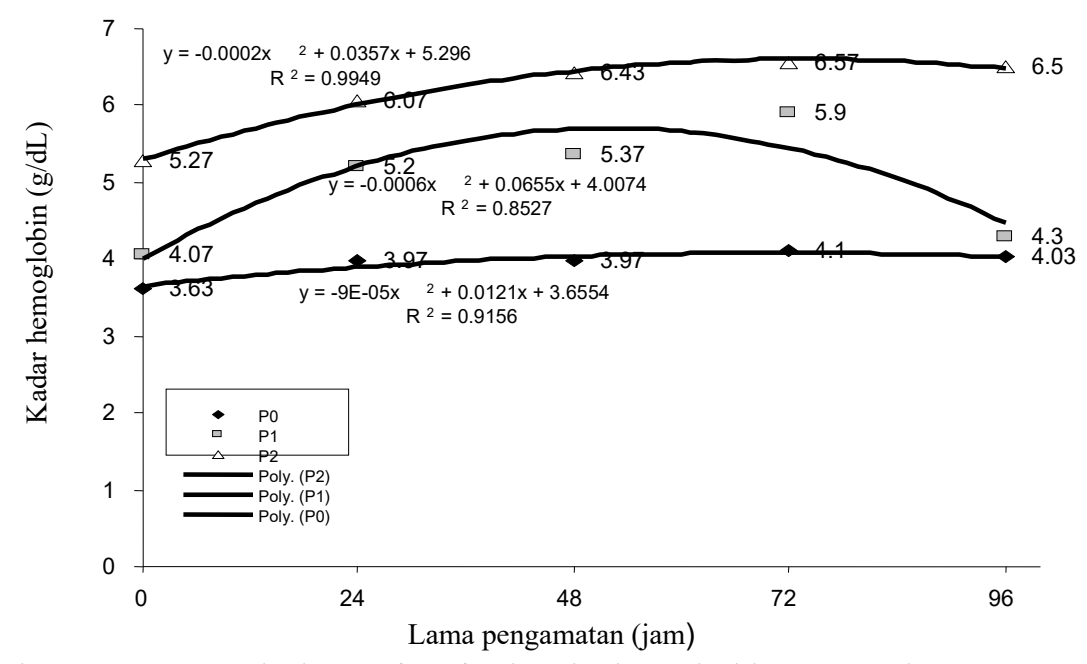

Gambar 4. Hubungan antara dosis profenofosdan kadar $\mathrm{Hb}$ hingga 96 jam. Keterangan: $\mathrm{P} 0=$ kontrol; $\mathrm{P} 1=$ dosis $0,75 \mathrm{mg} / \mathrm{L} ; \mathrm{P} 2=$ dosis $1,50 \mathrm{mg} / \mathrm{L}$.

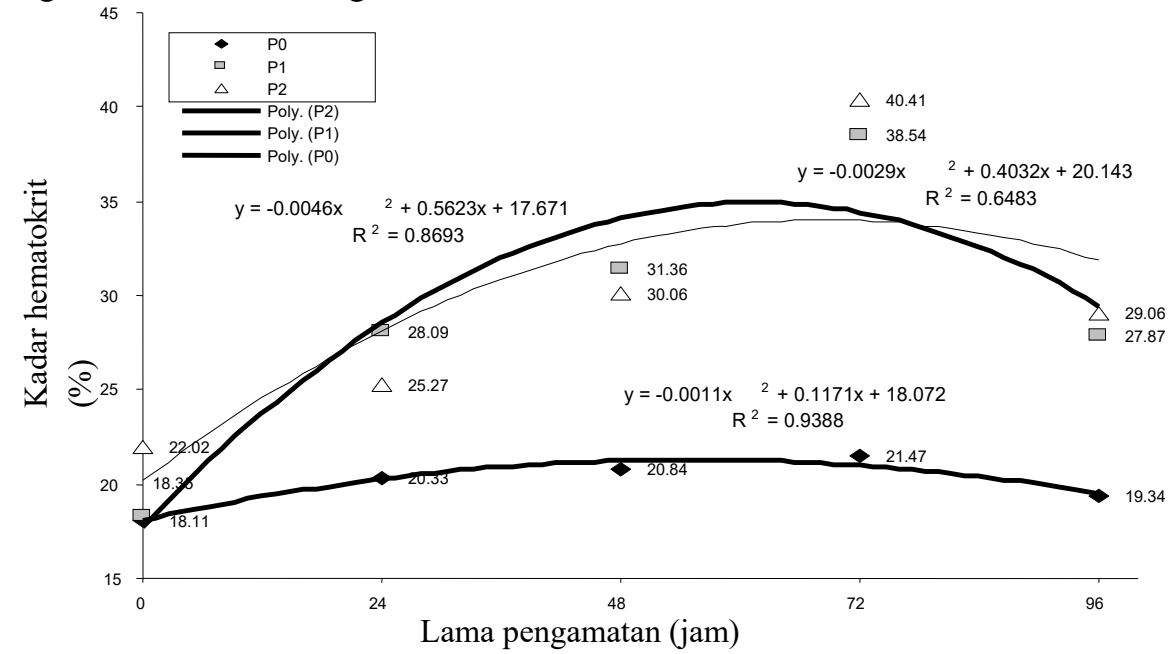

Gambar 5. Hubungan antara dosis profenofos dan hematokrit hingga 96 jam. Keterangan: $\mathrm{P} 0=$ kontrol; $\mathrm{P} 1=$ dosis $0,75 \mathrm{mg} / \mathrm{L} ; \mathrm{P} 2=$ dosis $1,50 \mathrm{mg} / \mathrm{L}$.

Peningkatan hematokrit sejalan dengan peningkatan hemoglobin, diduga karena pembentukan hemoglobin berlangsung normal. Selsel darah merah yang meningkat mengandung banyak hemoglobin untuk mengangkut oksigen yang dibutuhkan ketika konsumsi oksigen meningkat karena hipoksia.

Kontaminasi insektisida profenofos pada dosis dan lama pendedahan tertentu terbukti mengganggu aktivitas fisiologis ikan nila merah (Oreochromis sp.). Gangguan fisiologis tersebut meliputi gangguan pada aktivitas kolinesterase di otak dan plasma, gangguan pada laju konsumsi oksigen dan hematologi pada ikan. Bahkan pada dosis 2.105 $\mathrm{mg} / \mathrm{L}$ telah mampu mengakibatkan 50\% ikan mati dalam waktu 96 jam. Pada era keterbatasan lahan dan kebutuhan pangan yang terus meningkat seperti saat ini penggunaan insektisida merupakan suatu hal yang sulit dihindari, namun ketelusuran adanya limbah pertanian dan monitoring penggunaan secara terus menerus dapat mencegah dan mengurangi dampak kontaminasi insektisida bagi kehidupan organisme air.

\section{KESIMPULAN}

Aktivitas kolinesterase plasma darah yang terkontaminasi profenofos lebih rendah dibandingkan aktivitas kolinesterase jaringan otak. Pendedahan profenofos pada dosis dan lama pendedahan tertentu meningkatkan laju konsumsi oksigen, kadar hemoglobin dan hematokrit ikan nila merah (Oreochromis sp.). Dampak penggunaan insektisida dapat diminimalkan dengan penggunaan insektisida ramah lingkungan dan monitoring kesehatan lingkungan perairan secara menyeluruh dan berkelanjutan. 


\section{DAFTAR PUSTAKA}

Anonim, 2000. Profenofos Facts. United States Environmental Protection Agency, Washington.

Anonim, 2015. Laju Pertumbuhan Penduduk per Tahun. Badan Pusat Statistik. www.bps.go.id. Diakses pada tanggal 4 November 2015.

Anonim, 2015 . Produksi Padi Menurut Provinsi (ton). Badan Pusat Statistik. www.bps.go.id. Diakses pada tanggal 4 November 2015.

Bakhshwan, S.A., Marzouk., M.S., Hanna, M.I., dan Hamed, H.S., 2009. Some Investigations on The Clinical and Biogeochemical Alterations Associated with Dizinon Toxicity in Clarias gariepinus. Egypt J. Aquat. Biol. \& Fish, 13(2):173-197.

Banks, W.J., 1981. Applied Veterinary Histology. Williams \& Wilkins, Baltimore, London, pp 180-182.

Carvalho, C.S., dan Fernandes, M.N., 2006. Effect of Temperature on Copper Toxicity and Hematological Responses in the Neotropical Fish Prochilodus scrofa at Low and High $\mathrm{pH}$. J. Aquat., 251:109-117.

Cong, N.V., Phuong, N.T., dan Bayley, M., 2008. Brain Cholinesterase Response in Snakehead Fish (Channa striata) After Field Exposure to Diazinon. Ecotoxicol. \& Environ. Safe., 71:314-318.

Dalimunthe, K.T., Hasan, W., dan Ashar, T. 2012. Analisa Kuantitatif Residu Insektisida Profenofos pada Cabai Merah Segar dan Cabai Merah Giling di Beberapa Pasar Tradisional Kota Medan Tahun 2012. Jurnal Lingkungan dan Keselamatan Kerja, 1(1):1-5.

Griffin, R., 1999. Human Health Risk Assessment Profenofos., U.S. Environmental Protection Agency, Washoington.

Jan, M.T., Abbas, N., Shad, S.A., dan Saleem, M.A., 2015. Resistance to Organophosphate, Pyrethroid and Biorational Insecticides in Populations of Spotted Bollworm, Earias vittela (Fabricius) (Lepidoptera: Noctuidae), in Pakistan. Crop Protect., 78:247-252.

Kadim, M.K., Sudaryanti, S., dan Yuli H.E., 2013. Pencemaran Residu Pestisida di Sungai Umbulrejo Kecamatan Dampit Kabupaten Malang. Jurnal Manusia dan Lingkungan, 20(13):262-268.

Kazemi, M., Tahmasbi, A.M., Valizadeh, R., Naserian, A.A., dan Soni, A., 2012. Organophosphate Pesticides: A General Review. Agric. Sci. Res. J., 2(9):512-522.
Mattsson, K., Lehtinen, K.J., dan Tana, J., 2001. Effects of Pulp Mill Effluents and Restricted Diet on Growth and Physiology of Rainbow Trout (Oncorhynchus mykiss). Ecotoxicol. and Environ. Safe., 49:144-154.

Paudyal, B.P., 2008. Organophosphorus Poisoning. J. Nepal Med. Ass., 47(172):251-258.

Raini, M., 2007. Toksikologi Pestisida dan Penanganan Akibat Keracunan Pestisida. Media Litbang Kesehatan, 17(3):10-18.

Rumampuk, N.D., Tilaar, S., dan Wullur, S., 2010. Median Lethal Concentration (LC-50) Insektisida Diklorometan Pada Nener Bandeng (Chanos-chanos Forks). Jurnal Perikanan dan Kelautan, 6(2):87-91.

Setiarso, P., Buchari, Noviandri, I., dan Mujahidin, D., 2011. Analisis Diazinon Secara Diferensial Pulsa Voltametri Dibandingkan dengan Kromatografi. Jurnal Manusia dan Lingkungan, 18(2):105-13.

Singh, R.M., 2013. Acute Toxicity of an Organophosphate, Dimethoate to an Air Breathing Fish, Colisa fasciatus (B1.\&Schn). Indian J. Sci. Res. 4(1):97-100.

Srivastava, A.P., Mishra, D., Shrivastava, S., Srivastav, S.K., dan Srivastav A.K., 2010. Acute Toxicity and Behavioural Responses of Heteropneustes fossilis to An Organophosphate Insecticide, Dimethoate. Internat. J. Pharma. \& Bio. Sci., 1(4):359-363.

Supriyono, E., Pong-Masak, P.R., dan Naiborhu, P.E., 2005. Studi Toksisitas Insektisida Triklorfon Terhadap Ikan Nila, Oreochromis sp. Jurnal Akuakultur Indonesia, 4(2):163-170.

Tarwotjo, U., Situmorang, J., Soesilohadi, R.C.H., dan Martono, E., 2014. Monitoring Resistensi Populasi Plutella xylostella, L Terhadap Residu Emamektin Benzoat di Sentra Produksi Tanaman Kubis Propinsi Jawa Tengah. Jurnal Manusia dan Lingkungan, 21(2):202-212.

Taufik, I., Koesoemadinata, S., Sutrisno, dan Nugraha, A., 2002. Potensi Akumulasi Insektisida Klorpirifos Etil dalam Jaringan Tubuh Ikan Nila (Oreochromis niloticus). Jurnal Penelitian Perikanan Indonesia, 8(3):37-43.

Wang, Y., Chen, C., Zhao, X., Wang, Q., dan Qian, Y., 2015. Assessing Joint Toxicity of Four Organosphosphate and Carbamate Insecticides in Common Carp (Cyprinus carpio) Using Acetylcholinesterase Activity as An Endpoint. Pes. Biochem. and Physiol., 122:81-85. 